\title{
Antifungal potential of crude extracts of Trichoderma spp.
}

\author{
Eder Marques ${ }^{1,2}$, Irene Martins ${ }^{I}$ \& Sueli Correa Marques de Mello ${ }^{1,2, *}$ \\ ${ }^{1}$ Empresa Brasileira de Pesquisa Agropecuária, Embrapa Recursos Genéticos e Biotecnologia, Controle Biológico, \\ Laboratório de Fitopatologia, Brasília, DF, Brazil \\ ${ }^{2}$ Universidade de Brasilia, Instituto de Biologia, Depto. de Fitopatologia, Brasília, DF, Brazil \\ *Corresponding author: Sueli Correa Marques de Mello, e-mail: sueli.mello@embrapa.br
}

MARQUES, E., MARTINS, I., MELLO, S. C. M. Antifungal potential of crude extracts of Trichoderma spp. Biota Neotropica. 18(1): e20170418. http://dx.doi.org/10.1590/1676-0611-BN-2017-0418

\begin{abstract}
Antibiosis is the mechanism by which certain microorganisms respond to the presence of others, secreting compounds or metabolites capable of inhibiting or impeding their development. The crude extract of Trichoderma contains a mixture of secondary compounds, which may show antibiotic effect, and has been used for the prospect of this fungus for biological control and other industrial purposes. Faced with the increasing demand of agriculture for ecologically compatible alternatives for the management of diseases, this work aimed to investigate the spectrum of action of NonVolatile Metabolites (NVMs) of Trichoderma isolates against different plant pathogenic fungi. The antagonistic potential of NVMs was evaluated through the incorporation method of the filtered liquid extract in PDA medium. The assays showed that all the NVMs produced inhibited the fungus Sclerotinia sclerotiorum similarly. On the other hand, strains CEN1245 and CEN1274, both belonging to the species Trichoderma brevicompactum, showed broad spectrum against Sclerotium rolfsii, Colletotrichum gloesporioides, Verticillium dahliae, Fusarium oxysporum and Cylindrocladium $\mathrm{sp}$. The present study describes isolates producing non-volatile metabolites with broad spectrum of antifungal action, as well as pathogen-specific. The Trichoderma spp. NVMs obtained from different soil samples cultivated with vegetables, cassava and maize were efficient in inhibiting plant pathogenic fungi belonging to other patossystems, such as forest or fruit, which could increase their potential application in biological control of plant diseases. In addition, these antagonistic fungi should be studied in greater depth for the identification of bioactive molecules of industrial interest or in commercial formulations of products for biological control of plant pathogens.
\end{abstract}

Keywords: secondary metabolites, antagonism, inhibition of mycelial growth, plant pathogenic fungi.

\section{Potencial antifúngico de extratos brutos de Trichoderma spp.}

Resumo: Antibiose é um mecanismo pelo qual certos microrganismos respondem à presença de outros, secretando compostos ou metabólitos capazes de inibir ou impedir o seu desenvolvimento. O extrato bruto de Trichoderma contém uma mistura de compostos secundários e tem sido utilizado na prospecção deste fungo para o controle biológico e demais fins industriais. Diante da crescente demanda da agricultura por alternativas ecologicamente compatíveis para o manejo de doenças, este trabalho teve como objetivo investigar o espectro de ação de Metabólitos Não Voláteis (MNVs), produzidos por isolados de Trichoderma, contra diferentes fungos fitopatogênicos. O potencial antagônico dos MNVs foi avaliado através do método de incorporação do extrato líquido filtrado em meio BDA. Os ensaios mostraram que todos os MNVs produzidos inibiram de forma semelhante o fungo Sclerotinia sclerotiorum. Por outro lado, os isolados CEN1245 e CEN1274, ambos Trichoderma brevicompactum, mostraram um amplo espectro de ação, atuando contra Sclerotium rolfsii, Colletotrichum gloesporioides, Verticillium dahliae, Fusarium oxysporum e Cylindrocladium sp. O presente estudo descreve isolados que produziram metabólitos não voláteis com amplo espectro de ação antifúngico, assim como patógeno-específico. Os MNVs de Trichoderma spp. obtidos de diferentes amostras de solo cultivadas com vegetais, mandioca e milho, foram eficientes na inibição de fungos fitopatogênicos pertencentes a outros patossistemas, como os de espécies florestais e frutíferas, o que poderia aumentar sua potencial aplicação no controle de doenças de plantas. Adicionalmente, estes fungos antagonistas devem ser mais bem estudados para identificação de moléculas bioativas de interesse industrial ou formulação de produtos para o controle biológico de patógenos de plantas.

Palavras-chave: metabólitos secundários, antagonismo, inibição do crescimento micelial, fungos fitopatogênicos. 


\section{Introduction}

Trichoderma Persoon is a hyperparasite fungus that uses different mechanisms of biological control, which include: parasitism, antibiosis, competition, induction of resistance and growth promotion (Kumar 2013). Antibiosis is the mechanism by which certain microorganisms respond to the presence of others, secreting compounds or metabolites capable of inhibiting or preventing their development (Benítez et al. 2004). According to Dennis \& Webster (1971a, b), antibiotic compounds may be Volatile Metabolites (VMs) and Non-Volatile Metabolites (NVMs). Although these molecules are not essential, in some cases they are important for the selective survival of organisms under certain conditions (Donidio \& Monciardini 2002), eliminating microbial competition and, consequently, leading to greater availability of scarce food sources in the soil (Benítez et al. 2004). Raw metabolites consist of mixtures of compounds resulting from primary or secondary metabolism (Yamaguchi 1996). Primary metabolites (polysaccharides, fatty acids and nucleic acids) are common to all biological systems and are produced in the $\log$ phase of growth. Secondary metabolites (SMs) are produced during the stationary phase and in lesser quantities than the primary ones, encompassing a diversified class of low molecular weight substances and produced by specific groups of organisms (Hanson 2003), which include antibiotics.

Weidling (1941) described gliotoxin, isolated from the fungus Gliocladium fimbriatum Gilman \& Abbott, which was one of the first SM described and associated with antifungal action. At the present time, several SMs have been reported, and these are the main groups found in Trichoderma isolates: polyketides, peptaibols, terpenoids/steroids; pyrones and daucanes (Zeilinger et al. 2016). The SMs may play an antibiotic function against plant pathogens (Daoubi et al. 2009, Takhiro et al. 2013), act as a plant growth regulator, and have pharmacological properties for use as antiaging agents, cholesterol lowering agents, cancer cell fighters, immunological suppressors (Keswani et al. 2014) and flavoring for the food industry (Fadel et al. 2015).

Levels of biological control exerted on a target organism vary according to the antagonistic isolate, and therefore vary both intra and interspecifically (Dennis \& Webster 1971a, b, Brodeur 2012). In the context of the selection of these biocontrol agents, in vitro assays are used as indicative of the mode of action of the antagonist (Carvalho Filho et al. 2008). The evaluation of NVMs produced by fungi under laboratory conditions, as well as dual culture, is an initial step in the prospection of metabolites for both biological control and other purposes and can not be overlooked. It can be performed by the technique of cellophane paper (Khalili et al. 2012, Jeyaseelan et al. 2014, Barari 2016) or also from the liquid culture, filtration and incorporation in the substrate method. Numerous scientific studies have used the methodology of incorporation of filtrates into culture medium for the evaluation of antagonism in different plant pathogenic fungi species, such as Verticillium dahliae Kleb. (Jamdar et al. 2013), Sclerotium rolfsii Sacc. (Darvin et al. 2013, Isaias et al. 2014, Srinivasa et al. 2014), Sclerotinia sclerotiorum Lib. De Bary and Fusarium oxysporum Schlecht, Snyder \& Hansen (Jaspal et al. 2009, Castillo et al. 2011, Carvalho et al. 2011, Saxena et al. 2014), Colletotrichum spp. (Martins et al. 2007, Ajith \& Lakshmidevi 2010, Farah \& Nasreen 2013) and Cylindrocladium sp. (Carvalho Filho et al. 2008).

Although this biocontrol agent has been studied for a long time, including in Brazil, the industry still needs new isolates with potential for use in Integrated Pest Management programs (IPM). Nowadays, according to the Brazilian Ministry of Agriculture Livestock and Food Supply (MAPA), only five bioproducts, formulated with either T. asperellum and T. harzianum, are available.

Faced with the increasing demand of agriculture for ecologically compatible alternatives for the management of diseases, this work aimed to investigate the spectrum of action of non-volatile metabolites of Trichoderma isolates against different plant pathogenic fungi.

\section{Material and methods}

\section{Origin of fungal isolates}

Eight isolates of Trichoderma from the Collection of Fungi for the Control of Plant Pathogens and Weeds of EMBRAPA (Brazilian Agricultural Research Corporate), already characterized and identified in previous studies (Marques et al. 2016), were used. According to the study cited, these isolates exhibited antifungal activity in dual culture tests in vitro against $S$. sclerotiorum, and the identification was performed based on the sequencing of regions ITS $1 / 2$ of ribosomal DNA (rDNA). In addition to $S$. sclerotiorum, six other plant pathogenic fungal isolates were used in the present study, all described in Table 1.

\section{Evaluation of the antifungal activity}

The methodology described by Dennis \& Webster (1971a) was used to evaluate the potential of NVMs (crude extract or filtered from cultures) produced by Trichoderma isolates against plant pathogenic fungi. Routine multiplications of both antagonists and pathogens was performed on plastic Petri dishes containing commercial Potato-Dextrose-Agar (PDA) medium. Incubation of the cultures occurred at $25{ }^{\circ} \mathrm{C}$ with

Table 1. Description of biocontrol agents and plant pathogenic fungi used in this study

\begin{tabular}{|c|c|c|}
\hline Collection code & Origin of the isolates & Fungi \\
\hline CEN1242 & Maize (Zea mays L.) & T. harzianum \\
\hline CEN1245 & Tomato (Solanum lycopersicum L.) & T. brevicompactum \\
\hline CEN1251 & Maize (Z. mays) & T. harzianum \\
\hline CEN1255 & Tomato (S. lycopersicum) & T. harzianum \\
\hline CEN1256 & Tomato (S. lycopersicum) & T. harzianum \\
\hline CEN1258 & Cassava (Manihot esculenta Crantz) & T. spirale \\
\hline CEN1270 & Cassava (M. esculenta) & T. spirale \\
\hline CEN1274 & Kale (Brassica oleracea var. acephala) & T. brevicompactum \\
\hline CEN216 & Common bean (Phaseolus vulgaris L.) & S. rolfsii \\
\hline CEN419 & Passion fruit (Passiflora edulis Sims) & C. gloeosporioides \\
\hline CEN1273 & Chickpeas (Cicer arietinum L.) & F. oxysporum \\
\hline CEN494 & Eucalyptus (Eucalyptus grandis Hill ex. Maiden) & Cylindrocladium sp. \\
\hline CEN788 & Strawberry (Fragaria $\mathrm{sp.}$ ) & V. dahliae \\
\hline CEN1147 & Common bean (P. vulgaris) & S. sclerotiorum \\
\hline
\end{tabular}


Table 2. Inhibition Index of Mycelial Growth (IMG \%) of plant pathogenic fungi after being confronted with filtrates from cultures of isolates of Trichoderma

\begin{tabular}{|c|c|c|c|c|c|c|}
\hline \multirow[b]{2}{*}{ Collection code } & \multicolumn{6}{|c|}{ Plant pathogenic fungi } \\
\hline & $\begin{array}{c}\text { Sclerotinia } \\
\text { sclerotiorum }\end{array}$ & $\begin{array}{c}\text { Fusarium } \\
\text { oxysporum }\end{array}$ & $\begin{array}{l}\text { Colletotrichum } \\
\text { gloeosporioides }\end{array}$ & $\begin{array}{c}\text { Sclerotium } \\
\text { rolfsii }\end{array}$ & $\begin{array}{c}\text { Verticillium } \\
\text { dahliae }\end{array}$ & $\begin{array}{c}\text { Cylindrocladium } \\
\text { sp. }\end{array}$ \\
\hline CEN1242 & $9.7 \mathrm{a}^{*}$ & $1.0 \mathrm{~b}$ & $1.0 \mathrm{~d}$ & $1.0 \mathrm{c}$ & $2.4 \mathrm{e}$ & $5.7 \mathrm{~b}$ \\
\hline CEN1245 & $9.2 \mathrm{a}$ & $8.2 \mathrm{a}$ & $6.8 \mathrm{bc}$ & $9.5 \mathrm{a}$ & $10.2 \mathrm{a}$ & $5.7 \mathrm{~b}$ \\
\hline CEN1251 & $8.9 \mathrm{a}$ & $1.0 \mathrm{~b}$ & $1.0 \mathrm{~d}$ & $5.0 \mathrm{~b}$ & $2.4 \mathrm{e}$ & $5.0 \mathrm{~b}$ \\
\hline CEN1270 & $8.9 \mathrm{a}$ & $1.0 \mathrm{~b}$ & $5.1 \mathrm{c}$ & $5.6 \mathrm{~b}$ & $5.5 \mathrm{c}$ & $5.3 \mathrm{~b}$ \\
\hline CEN1255 & $9.4 \mathrm{a}$ & $1.0 \mathrm{~b}$ & $1.0 \mathrm{~d}$ & $1.0 \mathrm{c}$ & $1.0 \mathrm{f}$ & $11.0 \mathrm{a}$ \\
\hline CEN1256 & $9.5 \mathrm{a}$ & $1.0 \mathrm{~b}$ & $1.0 \mathrm{~d}$ & $1.0 \mathrm{c}$ & $5.2 \mathrm{~cd}$ & $5.4 \mathrm{~b}$ \\
\hline CEN1258 & $8.9 \mathrm{a}$ & $1.0 \mathrm{~b}$ & $8.7 \mathrm{ab}$ & $1.0 \mathrm{c}$ & $4.3 \mathrm{~d}$ & $5.7 \mathrm{~b}$ \\
\hline CEN1274 & $9.1 \mathrm{a}$ & $7.7 \mathrm{a}$ & $9.2 \mathrm{a}$ & $5.7 \mathrm{~b}$ & $9.1 \mathrm{~b}$ & $5.9 \mathrm{~b}$ \\
\hline CV\%\%** & 5.2 & 6.5 & 17.3 & 11.5 & 6.5 & 4.6 \\
\hline
\end{tabular}

* Means followed by the same letter do not differ statistically by Tukey test $(\mathrm{P}<0.05) .{ }^{*} \mathrm{CV}$ : coefficient of variation.

a $12 \mathrm{~h}$ photoperiod for seven days. To obtain the liquid phase with the non-volatile metabolites, the Trichoderma isolates were grown in PD medium (Potato-Dextrose, without addition of agar) in an orbital shaker at $150 \mathrm{rpm}$ at $25^{\circ} \mathrm{C}$ with absence of light for seven days. After this period, the liquid part was collected by filtration on filter paper and centrifuged at $6.081 x \mathrm{~g}$ for removal of fungal spores that could hinder membrane sterilization. The liquid phase was filtered through cellulose membranes of $0.45 \mu \mathrm{m}$ diameter and incorporated into the PDA medium $\left(\sim 50^{\circ} \mathrm{C}\right)$ in a proportion of $25 \%(\mathrm{v} / \mathrm{v})$. Three replicates were prepared with agar discs ( $5 \mathrm{~mm}$ diameter) taken from pathogen cultures. The mycelial agar disks were deposited in the center of each Petri dish containing PDA medium, supplemented with the respective antagonist culture filtrates. Control plates consisted of mycelial agar disks of each pathogen deposited in PDA medium, with sterile distilled water added.

The evaluation of the radial mycelial growth of the pathogen was carried out by taking the measurements of the diameter of the colonies, in millimeters. These measurements were used to calculate the inhibition Index of Mycelial Growth (Menten et al. 1976), using the equation: $\operatorname{IMG}(\%)=\left[\left(\mathrm{D}_{\text {ctreat }}-\mathrm{D}_{\text {treat }}\right) / \mathrm{D}_{\text {ctreat }}\right] \times 100$, where $\mathrm{D}_{\text {ctreat }}=$ diameter of the radial mycelial growth of the pathogen in the control treatment without filtrates; $\mathrm{D}_{\text {treat }}=$ diameter of the radial mycelial growth of the pathogen in the treatment with the filtrates. These evaluations were performed when the entire surface of the medium, in the control treatment, was colonized by the pathogen.

\section{Statistical analysis}

IMG data were converted to $\sqrt{x}+1$ and used in analysis of variance (ANOVA), followed by Tukey test, at a level of 5\% probability of significance, using the program Assistat 7.6 beta (Silva \& Azevedo 2016).

\section{Results}

All Trichoderma isolates tested produced NVMs that were effective against $S$. sclerotiorum, with no significant statistical difference between them (Table 2). Against $F$. oxysporum, only isolates CEN1245 and CEN1274 produced non-volatile compounds capable of inhibiting this fungus. Different inhibition indices of mycelial growth of $C$. gloesporioides were observed in the treatments with NVMs produced by the isolates CEN1245, CEN1270, CEN1258 and CEN1274, but without significant statistical difference between them. The other isolates did not produce effective secondary compounds against this plant pathogenic fungus. Among the isolates tested against $S$. rolfsii, four produced antifungal substances; however, it was isolate CEN1245 that stood out. V. dahliae had mycelial growth inhibited by NVMs produced by almost all isolates tested except for CEN1255. The highest IMGs observed were, once again, produced by isolates CEN1245 and CEN1274, with significant statistical difference between them. Finally, all isolates produced SMs with activity against Cylindrocladium sp., although isolate CEN1255 stood out with the highest IMG (Table 2).

\section{Discussion}

Since all isolates produced active NVMs against $S$. sclerotiorum, the results were compared with those obtained in previously performed dual culture tests (Marques et al. 2016), and a greater inhibition was observed with the use of the culture filtrates than in the direct comparison between pathogen and antagonist. This fact suggests that the main mechanism of action of these isolates is antibiosis, that is, the production of secondary compounds with antibiotic properties. It was observed that the three different species, T. harzianum, T. spirale and T. brevicompactum were effective against the fungus that causes white mold (Figure 1). Saxena et al. (2014) reported maximum inhibition rates against this plant pathogenic fungus, using culture filtrates from T. harzianum and T. atroviride (Jaspal et al. 2009), while for Castillo et al. (2011) this index was higher with T. asperellum $N V M$. It is postulated, therefore, that this action by antibiosis is variable intra and interspecifically, corroborating the findings of Dennis \& Webster (1971a, b) and Brodeur (2012).

The same was verified with the other plant pathogenic fungi confronted. Thus, the isolate that produced metabolites with the greatest capacity for inhibition of $V$. dahliea was CEN1245, belonging to the species T. brevicompactum (Table 2), while Jamdar et al. (2013) and Isaias et al. (2014) observed a greater inhibitory effect against this pathogen, using filtrates from T. harzianum, T. koningii and T. koningiopsis. With F. oxysporum, the NVMs that led to the greatest inhibition of mycelial growth in this work were also those produced by $T$. brevicompactum (CEN1245 and CEN1274). There are reports of greater inhibition of $F$. oxysporum with metabolites of $T$. viride (Farah \& Nasreen 2013) and T. harzianum (Farah \& Nasreen 2013, Saxena et al. 2014). In addition to the filtrates from the last two of the aforementioned isolates of T. brevicompactum, another one also filtered from $T$. harzianum (CEN1258) inhibited the mycelial growth of $C$. gloesporioides. Several studies, such as those developed by Ajith et al. (2010), Jaspal et al. (2009) and Martins et al. (2007) reported the production of $T$. viride and T. harzianum metabolites as those with the highest antifungal potential of different species of Colletotrichum, among several other species tested.

In the tests with Cylindrocladium sp., the isolate CEN1255, from T. harzianum, was highlighted as to the potential inhibition of growth of this pathogen. The same was verified by Carvalho Filho et al. (2008) who, however, also selected a T. pseudokoningii isolate as highly active against this pathogen in NVMs production tests. As for $S$. rolfsii, the culture filtrate with the highest antifungal effect was T. brevicompactum (CEN1245), while in the literature the filtrates were T. harzianum (Saxena et al. 2014), T. viride (Darvin et al. 2013) and T. virens (Srinivasa et al. 2014), corroborating, once again, with Dennis \& Webster (1971a, b) and Brodeur (2012).

In the present study the intra and interspecific variation of the antifungal activity of Trichoderma isolates in relation to different plant pathogenic 

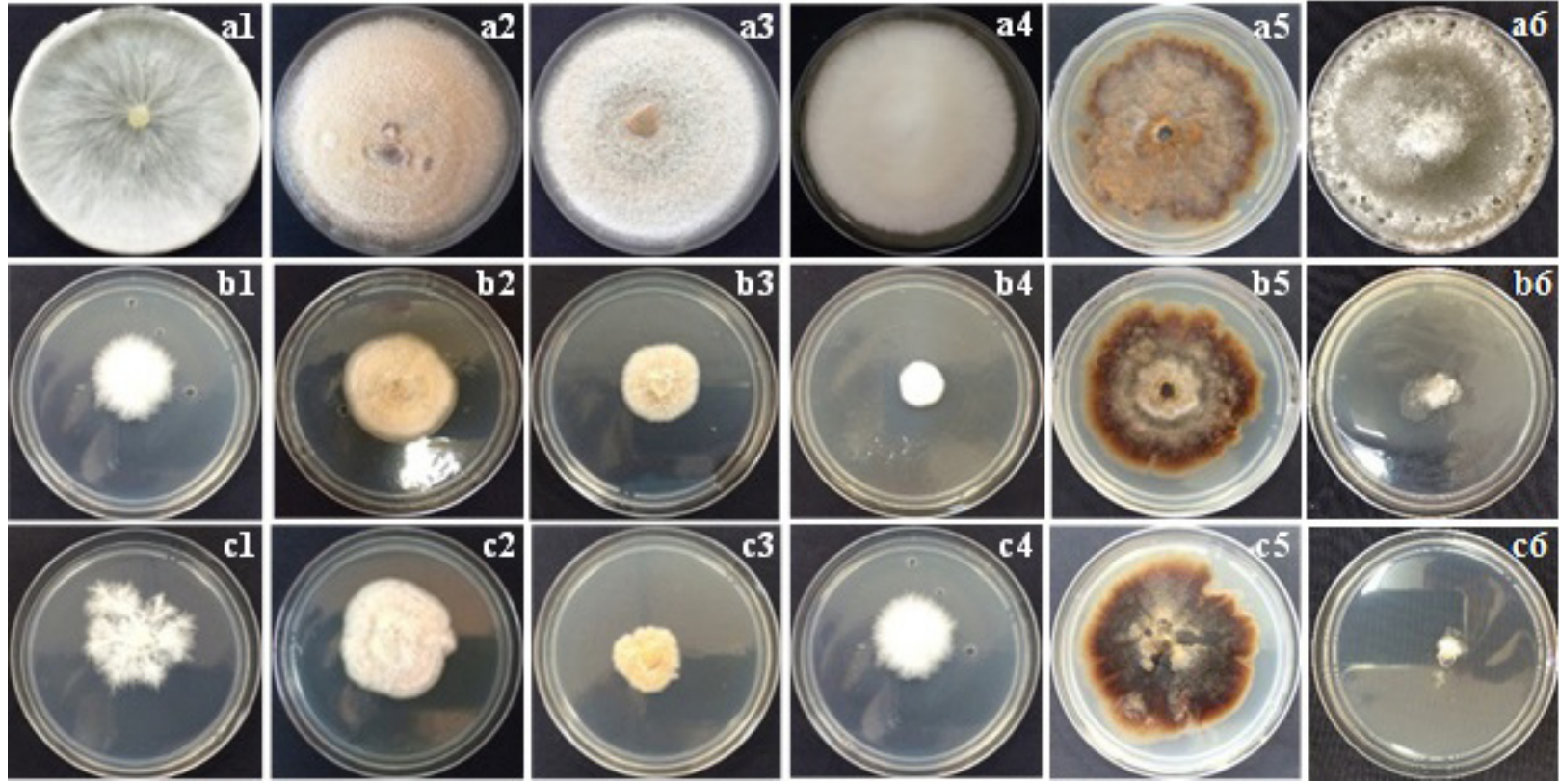

Figure 1. Effect of filtrates from cultures of Trichoderma spp. that stood out in the mycelial growth of plant pathogenic fungi, where a1-a6: Control treatments, b1-b6: treatments with the isolate CEN1245 and c1-c5: treatments with isolate CEN1274 and a1, b1 and c1: S. rolfsii (CEN216), a2, b2 and c2: F. oxysporum (CEN1273), a3, b3 and c3: C. gloesporioides (CEN419), a4, b4 and c4: V. dahliae (CEN788), a5, b5 and c5: Cylindrocladium sp. (CEN609) and a6, b6 and c6: S. sclerotiorum (CEN1147), respectively.

fungi was confirmed. Filtered cultures of the isolates of T. brevicompactum, CEN1245 and CEN1274, presented a broad antifungal spectrum, although isolates from other species were also prominent in the production of active metabolites with specificity against the plant pathogenic fungi used in the experiments. The Trichoderma metabolites obtained from different soil samples cultivated with vegetables, cassava and maize were effective to plant pathogenic fungi belonging to other patossystems such as forest or fruit trees, which could broaden their application in the biological control of plant diseases. In addition, the antagonistic fungi should be studied in greater depth for the identification of bioactive molecules of industrial interest or in commercial formulations of products for biological control of plant pathogens.

\section{Acknowledgements}

The authors are grateful for the financial support of CAPES (Coordination for the Improvement of Higher Education Personnel) and FAP-DF (Federal District Research Support Foundation).

\section{Author Contributions}

Sueli Correa Marques de Mello: substantial contribution in the concept and design of the study; contribution to manuscript preparation and critical revision.

Irene Martins: substantial contribution to data collection; contribution to data analysis and interpretation.

Eder Marques: substantial contribution in the concept and design of the study; contribution to data collection; contribution to data analysis and interpretation; contribution to manuscript preparation and critical revision.

\section{Conflicts of interest}

The authors declare that they have no conflict of interest related to the publication of this manuscript.

\section{References}

AJITH, P.S. \& LAKSHMIDEVI, N. 2010. Effect of volatile and non-volatile compounds from Trichoderma spp. against Colletotrichum capsici incitant of anthracnose on bell peppers. Nat. Sci. 8(9):265-269.

BARARI, H. 2016. Biocontrol of tomato Fusarium wilt by Trichoderma species under in vitro and in vivo conditions. Cercet. Agron. Mold. 49:91-98.

BENÍTEZ, T., RINCÓN, A.M., LIMÓN, M.C. \& CODÓN, A.C. 2004. Biocontrol mechanisms of Trichoderma strains. Int. Microbiol. 7(4):249-260.

BRODEUR, J. 2012. Host specificity in biological control: insights from opportunistic pathogens. Evol. Appl. 5(5):470-480.

CARVALHO, D.D.C., MELLO, S.C.M., LOBO JUNIOR, M. \& SILVA, M.C. 2011. Controle de Fusarium oxysporum f. sp. phaseoli in vitro e em sementes, e promoção do crescimento inicial do feijoeiro comum por Trichoderma harzianum. Trop. Plant Pathol. 36(1):28-34

CARVALHO FILHO, M.R., MENÊZES, J.E., MELLO, S.C.M. \& SANTOS, R.P 2008. Avaliação de isolados de Trichoderma no controle da mancha foliar do eucalipto in vitro e quanto a esporulação em dois substratos sólidos. Boletim de Pesquisa e Desenvolvimento, Brasília, 225. 21p.

CASTILlO, F.D.H., PADILlA, A.M.B., MORALES, G.G., SILLER, M.C., HERRERA, R.R., GONZALES, C.N.A. \& REYES, F.C. 2011. In vitro antagonist action of Trichoderma strains against Sclerotinia sclerotiorum and Sclerotium cepivorum. A. J. Agric. Biol. Scie. 6(3):410-417.

DAOUBI, M., PINEDO-RIVILLA, C., RUBIO, M.B., HERMOSA, R., MONTE, E., ALEU, J. \& COLLADO, I.G. 2009. Hemisynthesis and absolute configuration of novel 6-pentyl-2H-pyran-2-one derivatives from Trichoderma spp. Tetrahedron 69:4834-40.

DARVIN, G., VENKATESH, I. \& REDDY, N. 2013. Evaluation of Trichoderma spp. against Sclerotium rolfsii in vitro. Int. J. Appl. Biol. Pharm. (4):268-272.

DENNIS, C. \& WEBSTER, J. 1971a. Antagonistic properties of species-groups of Trichoderma. I. Production of non-volatile antibiotics. Trans. Br. Mycol. Soc. 57(1):25-39.

DENNIS, C. \& WEBSTER, J. 1971b. Antagonistic properties of species-groups of Trichoderma. II. Production of volatile antibiotics. Trans. Br. Mycol. Soc. 57(1):41-48. 
DONIDIO, S. \& MONCIARDINI, P. 2002. Microbial technologies for the discovery of novel bioactive metabolites. J. Biotechnol. 99(3):187-198.

FADEL, H.H.M., MOHMOUD, M.G. \& ASKER, M.M.S. 2015. Characterization and evaluation of coconut aroma produced by Trichoderma viride EMCC-107 in solid state fermentation on sugarcane bagasse. Electron. J. Biotechnol. 18(1):5-9.

FARAH, S.T. \& NASREEN, S. 2013. In vitro assessment of antagonistic activity of Trichoderma viride and Trichoderma harzianum against pathogenic fungi. Indian J. Appl. Res. 3(5):57-59.

HANSON, J.R. 2003. Natural Products: The Secondary Metabolites. Royal Society of Chemistry: Cambridge, pp.1772-1773.

ISAIAS, C.O., MARTINS, I., SILVA, J.B.T., SILVA, J.P. \& MELLO, S.C.M. 2014. Ação antagônica e de metabólitos bioativos de Trichoderma spp. contra os patógenos Sclerotium rolfsii e Verticillium dahliae. Summa Phytopathol. 40:(1)34-41.

JAMDAR, Z., MOHAMMADI, A.H. \& MOHAMMADI, S. 2013. Study of antagonistic effects of Trichoderma species on growth of Verticillium dahliae, the causal agent of Verticillium wilt of pistachio under laboratory condition. J. Nuts 4(4):53-56.

JASPAL, K., MUNSHI, G.D., SINGH, R.S. \& KOCK, E. 2009. Selection of biocontrol agents for the management of white rot of peas caused by Sclerotinia sclerotiorum. Plant. Dis. Res. 24(2):148-155.

JEYASEELAN, E.C., THARMILA, S. \& NIRANJAN, K. 2014. Antagonistic activity of Trichoderma spp. and Bacillus spp. against Pythium aphanidermatum isolated from tomato damping off. Arch. Appl. Sci. Res. 4(4):1623-1627

KHALILI, E., SADRAVI, M., NAEIMI, S. \& KHOSRAVI, V. 2012. Biological control of rice brown spot with native isolates of three Trichoderma. Braz. J. Microbiol. 43(1):297-305.

KESWANI, C., MISHRA, S., SARMA, B.K., SINGH, S.P. \& SINGH, H.B. 2014. Unraveling the efficient applications of secondary metabolites of various Trichoderma spp. Appl. Microbiol. Biotechnol. 98:533-544.

KUMAR, S. 2013. Trichoderma: A biological weapon for managing plant diseases and promoting sustainability. Int. J. Agrl. Sc. \& Vet. Med. 1(3):1-18.

MARTINS, I., PEIXOTO, J.R., MENÊZES, J.E. \& MELLO, S.C.M. 2007. Avaliação in vitro do antagonismo de Trichoderma spp. sobre Colletotrichum gloeosporioides. Boletim de pesquisa e desenvolvimento 193. Embrapa Recursos Genéticos e Biotecnologia, Brasília, 12p.

MENTEN, J.O.M., MINUSSI, C.C., CASTRO, C. \& KIMATI, H. 1976. Efeito de alguns fungicidas no crescimento micelial de Macrophomina phaseolina (Tass.) Goid. "in vitro". Fitopatol. Bras. 1:57-66.

MARQUES, E., MARTINS, I., CUNHA, M.O.C., LIMA, M.A., SILVA, J.B.T., SILVA, J.P., INGLIS, P.W., \& MELLO, S.C.M. 2016. New isolates of Trichoderma antagonistic to Sclerotinia sclerotiorum. Biota Neotrop. 16(3): e20160218. http:// dx.doi.org/10.1590/1676-0611-BN-2016-0218 (último acesso em 17/10/2017)

SAXENA, D., TEWARI, A.K. \& RAI, D. 2014. In vitro antagonistic assessment of T. harzianum PBT 23 against plant pathogenic fungi. J. Microbiol. Biotechnol. Res. 4(3):59-65.

SILVA, F.A.S. \& AZEVEDO, C.A.V. 2016. O Assistat Software Versão 7.7 e seu uso na análise de dados experimentais. Afr. J. Agric. Res. 11(39):3733-3740.

SRINIVASA, N., DEVI, P., SUDHIRJUMAR, S., KAMIL, D., BORAH, J.L. \& PRABHAKARAN. 2014. Bioefficacy of Trichoderma isolates against soilborne pathogens. Afr. J. Microbiol. Res. 8(28):2720-2723.

WEIDLING, R. 1941. Experimental consideration of the mold toxins of Gliocladium and Trichoderma. Phytopathol. 27:991.

ZEILINGER, S.Z., GRUBER S., BANSAL R. \& MUKHERJEE P. 2016. Secondary metabolism in Trichoderma - Chemistry meets genomics. Fungal Biol. Rev. 30(2):74-90.

YAMAGUCHI, I. 1996. Pesticides of microbial origin and application of molecular biology. In: Copping, L.G. (eds.), Crop Protection Agents from Nature: Natural Products and Analogues. Royal Society of Chemistry, Cambridge, UK. pp.27-49.

Received: 02/08/2017

Revised: 14/12/2017

Accepted: 15/12/2017

Published online: 01/02/2018 